\title{
ANALISIS PERAN KELUARGA DALAM MEMBENTUK KARAKTER ANAK
}

\author{
Oleh: Ainur Rofiq \\ Institut Pesantren KH. Abdul Chalim Mojokerto \\ E-mail: \\ Ismatun Nihayah \\ Institut Pesantren KH. Abdul Chalim Mojokerto \\ Email: ishmahnihayah@gmail.com
}

\begin{abstract}
Absrtak
Pembentukan karakter tidak bisa dilakukan secara maksimal oleh sekolah tanpa kerjasama dari keluarga. Keluarga merupakan pendidik pertama dan utama bagi anak dan menjadi dasar penting dalam pembentukan karakter anak. Anak diibaratkan seperti selembar kertas putih kosong yang harus diisi, dalam hal ini peran orang tualah yang sangat dominan mendidik anak semenjak dini, dengan penuh kelembutan dan kasih sayang membangun kebiasaan- pembiasan positif, mampu menjadi contoh yang baik.
\end{abstract}

Kata Kunci : Peran Keluarga, Karakter Peserta Didik

\section{A. Pendahuluan}

Pendidikan pada zaman sekarang bukan hanya dipandang pada jumlah peserta didik yang semakin bertambah kuantitasnya, akan tetapi harus bertambah juga kualitasnya dalam menahan beberapa masalah apabila menghadapi tantangan dan kondisi masyarakat yang saat ini semakin mengkhawatirkan. Pada dewasa ini sekolah telah membuktikan bahwa sekolah mampu membuat sebuah perubahan dalam mengembangkan karakter. Akan tetapi, apakah itu menjadi suatu tanggung jawab sekolah sepenuhnya? Apa keluarga tidak memiliki peran dalam hal tersebut?

Keluarga merupakan forum pendidikan pertama dan utama dalam sejarah hidup seorang anak, anak lebih banyak menghabis waktunya dengan keluarga dibanding gurunya, dan di sekolah para gurunya akan berubah setiap tahun, tetapi di luar sekolah anak akan dibimbing dan membesarkan mereka oleh orang tua yang sama selama bertahun-tahun. Dari penjelasan diatas, bisa dikatakan bahwa keluarga memberi dasar penting dalam membentukan karakter anak.

Anak diibaratkan sebagai kertas putih, yang menentukan kertas tersebut tetap putih atau tidak, salah satunya adalah orang tuanya. Fenomena yang dialami sekarang 
oleh sejumlah besar dalam pendidikan adalah orang tua menyerah tugas seutuhnya kepada sekolah. Justru itu membuat karakter anak tidak akan terbentuk dengan baik, karena tidak ada kesinambungan atau penguatan karakter yang ditanam oleh guru apabila anak di luar jam sekolah.

\section{B. Pembahasan}

\section{Pendidikan Karakter Anak}

Pengertian karakter secara etimologis, kata karakter berasal dari bahasa Latin kharakter atau bahasa Yunani kharassein yang berarti memberi tanda (to mark), atau bahasa Prancis carakter, yang berarti membuat tajam atau membuat dalam. Dalam bahasa Inggris character, memiliki arti: watak, karakter, sifat, dan peran. Dalam Kamus Besar Bahasa Indonesia, karakter diartikan sebagai tabiat, watak, sifat-sifat kejiwaan, akhlak, atau budi pekerti yang membedakan seseorang dari pada yang lain ${ }^{1}$.

Secara sederhada suatu nilai yang diwujudkan dalam bentuk perilaku itulah yang disebut karakter. Sedangkan pengertian pendidikan karakter itu, beberapa ahli mendefinisikan sebagai berikut:

Menurut T. Ramli (2003), pendidikan karakter memiliki esensi dan makna yang sama dengan pendidikan moral dan pendidikan akhlak. Tujuannya adalah membentuk pribadi anak, supaya menjadi manusia yang baik, warga masyarakat, dan warga negara yang baik.

Menurut Elkind dan Sweet (2004), pendidikan karakter dimaknai sebagai usaha yang sungguh-sungguh untuk membantu orang memahami, peduli, dan bertindak berdasarkan nilai-nilai etika inti.

Menurut Kevin Ryan dan Bohlin (2001), pendidikan karakter adalah sebagai upaya sungguh-sungguh untuk membantu seseorang memahami, peduli, dan bertindak dengan landasan inti nilai-nilai etis. ${ }^{2}$

\footnotetext{
1 Muhammad Anas Ma`arif, "Analisis Strategi Pendidikan Karakter Melalui Hukuman Preventif," Ta'allum: Jurnal Pendidikan Islam 6, no. 1 (6 Maret 2018): 31-56, https://doi.org/10.21274/taalum.2018.6.1.31-56.

${ }^{2}$ Fathurrohman P. dkk. 2017. Pengembangan Pendidikan Karakter. Bandung: PT Refika Aditama. Hlm. $15-18$
} 
Berdasarkan pengertian di atas dapat dipahami bahwa karakter itu identic dengan akhlak, sehingga karakter merupakan nilai-nilai prilaku manusia yang meliputi seluruh aktivitas manusia, baik berhubungan dengan Tuhannya, dengan dirinya, dengan sesama manusia, maupun dengan lingkungannya, yang terwujud dalam pikiran, persaan, perkatan, sikap dan perbuatan berdasar norma-norma agama, tata karma, hukum, budaya, dan adat istiadat ${ }^{3}$.

\section{Peran Keluarga (Orang Tua) Dalam Membentuk Karakter Anak}

\section{a. Peran orang tua}

Faktor penentu bagi perkembangan anak baik fisik maupun mental adalah peran orang tua, terutama peran seorang ibu, karena ibu adalah pendidik pertama dan utama bagi anak- anak yang dilahirkan sampai dia dewasa. Dalam proses pembentukan pengetahuan, melalui berbagai pola asuh yang disampaikan oleh seorang ibu sebagai pendidik pertama sangatlah penting. Pendidikan dalam keluarga sangat berperan dalam mengembangkan watak, kepribadian, nilai-nilai budaya, nilai-nilai keagamaan dan moral ${ }^{4}$, serta ketrampilan sederhana. Dalam konteks ini proses sosialisasi dan enkulturasi terjadi secara berkelanjutan. Hal ini bertujuan untuk membimbing anak agar menjadi manusia yang beriman, bertaqwa, berakhlak mulia, tangguh, mandiri, inovatif, kreatif, beretos kerja, setia kawan, peduli akan lingkungan, dan lain sebagainya yang berguna pada diri anak sendiri, masyarakat dan bangsa. ${ }^{5}$

Searah dengan penjelasan di atas, Thomas Lickona mengatakan bahwa secara umum orang-orang memandang keluarga merupakan sumber pendidikan moral yang paling utama bagi anak-anak. Mereka adalah guru pertama dalam mendidik moral. Hubungan antar orang tua dan anak dipengaruhi dengan berbagai perbedaan khusus dalam hal emosi, yang menyebabkan anak merasakan dicintai dan dihargai atau sebaliknya. ${ }^{6}$

${ }^{3}$ Muhammad Anas Ma`arif dan Muhammad Husnur Rofiq, "The Role of Islamic Education Teachers in Improving the Character of Nationalism in Boarding School," EDUKASI: Jurnal Pendidikan Islam 6, no. 1 (21 Juni 2018): 064-078, https://doi.org/10.5281/edukasi.v6i1.323.

${ }^{4}$ Abdul Muhaimin, "Strategi Pendidikan Karakter Perspektif Kh. Hasyim Asy'ari," Nidhomul Haq: Jurnal Manajemen Pendidikan Islam 2, no. 1 (26 November 2017): 26-37.

${ }^{5}$ Permono, H. 2013. Peran orang Tua dalam Optimalisasi tumbuh Kembang Anak Untuk Membangun Karakter Anak Usia Dini. Prosiding Seminar Nasional Parenting, A.0, hlm. 33

${ }^{6}$ Lickona T. 2016. Educating for Character. Jakarta: Bumi Aksara. Hlm. 48 
Maka kondisi dan suasana dalam keluarga ikut berpengaruh terhadap pendidikan karakter seorang anak, suasana keluarga tanpa kekerasan menjadi salah satu solusi yang sangat efektif untuk membuat seorang anak merasa nyaman, damai dan tenreram apabila berada di rumahnya, akhirnya anak memiki emosi yang stabil sehingga karakter yang baik akan terbentuk. Demi waktu ke waktu kita tidak bisa menafi akan gaya mendidik anak yang bermacam-macam yang dilakukan oleh orang tua sekarang. Banyak orang tua menghabis waktunya dengan urusan di luar rumah, rutinitas kantor, aktivitas organisasi dan lain sebagainya, sehingga anak dididik dengan emosi yang tinggi atau anak diabaikan dengan diberi sebuah gadget yang canggih untuk menemani mereka ${ }^{7}$.

Dalam mendidik anak, keluarga atau orang tua ada banyak peran yang akan mempengaruhi pola pikir dan perilaku dari seorang anak :

1) Orang tua dapat memberikan penjelasan mengenai hal baik dan buruk bagi anak, penting bagi anak untuk mendapat penjelasan terhadap kelakuan itu boleh dilakukan atau tidak dengan 4aying yang mudah mengerti.

2) Pendidikan yang keras juga akan menyebabkan anaknya menjadi keras, menggunakan pola pendidikan yang keras akan menyebabkan anak-anak menjadi disiplin, namun malah juga akan meningkatkan kemungkinan seorang anak untuk tidak nyaman.

3) Apa yang dilakukan orang tua akan ditiru oleh anak, anak akan mengikuti apa yang menjadikan kebiasaan orang tuanya. Jadi dalam mendidik anak untuk memiliki karakter yang baik, orang tua harus memberi contoh yang positif kepada anak baik dalam tingkah laku atau berbicara.

4) Orang tua harus bisa menjaga anaknya dari lingkungan social yang buruk. Apabila orang tua sudah mendidik anaknya dengan baik, maka disamping itu orang tua harus bisa menjaga atau mengawas anaknya dalam kehidupan bersosial.

5) Memberi kasih saying dan semangat, orang tua harus memberi kasih 4aying dan menghargai anak, baik di saat mereka mendapatkan nilai ujian yang bagus maupun ketika mereka tidak mendapat hasil yang diinginkan karena sesungguhnya mereka telah bekerja keras.

7 Ahmad Fauzi, "Kepemimpinan Kepala Madrasah Dalam Mengembangkan Lembaga Pendidikan Islam," Nidhomul Haq: Jurnal Manajemen Pendidikan Islam 2, no. 2 (6 Desember 2017): 42-53. 


\section{b. Kapan pendidikan anak dimulai}

Perspektif Islam, pendidikan anak dimulai saat bayi masih ada dalam kandungan ibu, dengan cara memberikan makanan yang halal, komunikasi, mendengarkan ayat-ayat suci Al-Quran, musik klasik, yang dapat membantu perkembangan otak anak ${ }^{8}$.

Ada anggapan bahwa pendidikan baru bisa dimulai setelah usia sekolah dasar, ternyata tidak benar, bahkan pendidikan yang dimulai usia taman kanak-kanakpun sebenarnya sudah terlambat. Menurut hasil penelitian di bidang neurologi seperti yang dilakukan oleh Dr. Benyamin S. Bloom, seorang ahli pendidikan dari universitas Chicago, Amerika Serikat, mengemukakan bahwa pertumbuhan sel jaringan otak pada anak usia 0-4 tahun mencapai 50\% (Cropley,1994). ${ }^{9}$ Artinya bila pada usia tersebut otak anak tidak mendapatkan rangsangan yang maksimal maka segala tumbuh kembang anak baik fisik maupun mental tidak akan berkembang secara optimal.

Ada beberapa hal yang dapat kita lakukan untuk membentuk watak dan kepribadian anak yang baik, antara lain adalah:

1) Mengenalkan Allah SWT sejak dini, pengenalan kepada Allah SWT seharusnya sudah dimulai sejak anak masih berada di dalam kandungan. Pada saat itu, bayi sudah dapat mendengar, karenanya saat mengandung, seorang ibu disunnahkan untuk banyak berdzikir dan menjauhi majelis ghibah, tujuannya supaya anak hanya mendengar yang baik saja. Pada saat kelahiran seorang bayi disunnahkan untuk segera mengadzankan bayi di telinga kanan dan mengiqomatkan bayi ditelinga kiri, upaya ini mempengaruhi penanaman dasar aqidah, tauhid dan iman bagi anak.

2) Menjauhkan kata-kata tidak baik di hadapan anak. Setiap hari seorang bayi menangkap kata- kata ibu dan ayahnya. Ibu adalah orang yang paling sering dekat dengan si bayi dan yang paling sering memeluknya dalam sehari, karenanya daya hidup sang bayi menyerap suara ibunya bersamaan dengan setiap aspek keberadaan ibunya. Sama seperti sebuah perekam,

${ }^{8}$ Muhammad Anas Ma'arif, "Analisis Konsep Kompetensi Kepribadian Guru PAI Menurut AzZarnuji,” ISTAWA 2, no. 2 (2017): 35-60.

${ }^{9}$ Permono, H. Hlm. 35-36 
bayi akan menggunakan nalurinya untuk menyerap setiap hal di lingkungannya ketika ia sedang belajar menjadi manusia.

3) Biasakan anak untuk jujur. Berhati-hatilah terhadap kata-kata yang kita ajarkan dan ucapkan, jangan sampai di dalamnya terdapat benih-benih kebohongan. Orang tua adalah teladan bagi anak.

4) Beri contoh dalam menjaga amanah. Anak adalah seorang peniru maka orang tua berkewajiban memberi contoh yang baik. Ajaklah anak sholat tepat waktu, ketika umurnya tujuh tahun, saat dia melalaikan sholat pukul dia, hal ini dikarenakan untuk mengajari dia dalam menjaga amanah atau belajar tanggung jawab. Apabila anak waktunya belajar tetapi dia masih menonton TV maka tegur dia lalu matikan televisinya, suruh si anak untuk belajar dan kita jangan menyalakan lagi TV itu. Kita temani anak untuk belajar dan menanyakan kesulitan-kesulitannya.

5) Mendengarkan kritikan/ teguran anak. Mendengarkan serta menghargai kritikan anak bukanlah sebuah hinaan yang akan merendahkan martabat sebagai orang tua, namun merupakan anugrah bagi orang tua memiliki anak yang kritis, akan tetapi kita harus mengajarkan cara mengkritik yang santun.

6) Berbuat Adil,anggaplah kita sebagai hakim yang adil dalam menghadapi masalah yang dialami oleh anak- anak baik antara kakak dengan adik maupun antara anak kita dengan orang lain, lihat dulu apa permasalahannya? Mana yang salah? Jangan asal menyalahkan!

7) Luangkan waktu untuk bermain bersama anak, mendengarkan keluh kesahnya sehingga anak akan merasa lega dengan berkurangnya beban yang ada di hatinya.

8) Ajaklah anak untuk mengambil setiap ilmu dimana saja dia berada. Sediakan bacaan yang bermutu bagi anak di rumah, kondisikan agar dia mau dan senang membaca. Ajarkan bahwa mendapatkan ilmu bisa dari siapa saja, ini juga mengajarkan untuk emnghargai orang lain. ${ }^{10}$

10 Hyoscyamina Darosy, E. (2011). Peran Keluarga dalam Membangun Karakter Anak. Jurnal Psikologi Undip Vol. 10, No.2, Hlm 148-149 


\section{c. Mendidik anak dengan komunikasi}

Saat ini sebagian besar orang tua yang berhasil mendidik anak-anaknya dengan cara komunikasi dua arah dan hubungan yang dilandasi dengan kasih sayang. Komunikasi yang tepat akan memudahkan anak ataupun orang tua untuk menyampaikan apa yang ia rasakan ataupun yang diketahui. Dengan komunikasi orang tua dapat mengenal setiap anaknya sebagai pribadi yang unik, dan dapat menjalin hubungan yang akrab dengan anaknya.

Banyak masalah yang muncul karena kurang berkomunikasi antar orang tua dan anak. Kadang orang tua senang memberi perintah tanpa berkomunikasi atau menerima penjelasan dan pertanyaan dari anak tentang hal yang diperintah, sehingga ada kesalahpahaman di antara orang tua dan anak. Adapun anak lebih senang berkomunikasi atau curhat masalah yang dihadapi kepada teman sebaya dibanding orang tuanya, karena mereka anggap bahwa orang tua kurang mengerti mereka.

Untuk mengatasi masalah antara otang tua dan anak, ada tiga teknik komunikasi yang paling penting untuk dapat membangun jenis hubungan yang penuh kasih sayang dalam keluarga, yaitu:

1) Bercerita, orang tua dapat mendidik anaknya dengan bercerita. Orang tua yang bersedia membuka diri kepada anaknya akan mendorong keterbukaan diri anak. Dengan memberikan kesempatan pada anak-anak untuk bercerita tentang apa yang dialaminya maka akan membantu anak agar lebih membuka diri, dapat menerima kritik dan saran, memperbaiki diri serta membantu anak untuk dapat lebih mengemukakan apa keinginan mereka. Jadi anak lebih terbuka dengan orang tua mereka. Anak yang tidak pernah berbagi pengalaman dengan orang tua, maka akan menjadi anak yang cenderung menutup diri dan tidak dapat mengekspresikan $\operatorname{diri}^{11}$.

2) Mendengarkan, kemampuan untuk mendengarkan orang lain, merupakan suatu hal yang penting untuk membina hubungan dalam keluarga. Pada hakikatnya mendengar adalah menerima sampai suatu cerita berakhir, serta berusaha untuk menyusun kembali dalam pikiran kita peristiwa-peristiwa dan pengalaman-pengalaman orang lain. Pada saat anak menghadapai

${ }^{11}$ Muhammad Anas Ma`arif, "Pendidikan Islam Dan Tantangan Modernitas," Nidhomul Haq: Jurnal Manajemen Pendidikan Islam 1, no. 2 (26 Maret 2016): 47-58. 
suatu masalah orang tua hendaknya mendengarkan cerita anak sampai selesai sebelum orang tua memberikan solusinya.

3) Berempati, berarti mau ${ }^{12}$ merasakan apa yang dirasakan oleh orang lain. Menurut James Dobson seorang ahli jiwa mengatakan bahwa kunci untuk membesarkan anak yang sehat dan bertanggung jawab adalah dengan berusaha untuk merasa di balik mata si anak, artinya orang tua berusaha untuk melihat apa yang dilihat anak, memikirkan apa yang dipikirkan, dan merasakan apa yang dirasakan. Dengan berempati kita akan lebih dapat memahami keinginan dan kebutuhan anak. ${ }^{13}$

\section{Kesimpulan}

Pembentukan karakter anak itu tidak bisa dilakukan oleh sekolah tanpa kerjasama dari keluarga, karakter anak harus mulai dibentuk sejak anak dalam kandungan ibu sampai terbentuk karakter yang diinginkan. Keluarga sangat memberi pengaruh besar dalam pendidikan karakter seorang anak terutama ibu, karena ibu dapat diibaratkan sebagai guru yang pertama bagi seorang anak, apapun dilaku oleh ibu akan ditiru oleh anak.

Dalam pendidikan karakter seorang terhadap anak melalui komunikasi sangat berpengaruh, orang tua harus membentuk sebuah komunikasi yang baik antara orang tua dan anak. Ada tiga teknik komunikasi yang paling penting untuk dapat membangun jenis hubungan yang penuh kasih sayang dalam keluarga, yaitu berbicara, mendengarkan, dan berempati.

\section{Referensi}

Fathurrohman, P. dkk. (2017). Pengembangan Pendidikan Karakter. Bandung: PT Refika Aditama.

Lickona T. (2016). Educating for Character. Jakarta: Bumi Aksara.

Hyoscyamina Darosy, E. (2011). Peran Keluarga dalam Membangun Karakter Anak. Jurnal Psikologi Undip Vol. 10, No.2

Permono, H. (2013). Peran orang Tua dalam Optimalisasi tumbuh Kembang Anak Untuk Membangun Karakter Anak Usia Dini. Prosiding Seminar Nasional Parenting, A.0.

${ }^{12}$ Andika Aprilianto, "Karakteristik Individu Dan Persepsi Tentang Gaya Pengasuhan Terhadap Hasil Belajar Siswa," Nidhomul Haq: Jurnal Manajemen Pendidikan Islam 2, no. 2 (6 Desember 2017): 54-62, https://doi.org/10.31538/nidhomulhaq.v2i2.30.

${ }^{13}$ Hyoscyamina Darosy, E. Hlm. 150-151 
Aprilianto, Andika. "Karakteristik Individu Dan Persepsi Tentang Gaya Pengasuhan Terhadap Hasil Belajar Siswa." Nidhomul Haq : Jurnal Manajemen Pendidikan Islam 2, no. 2 (6 Desember 2017): 54-62. https://doi.org/10.31538/nidhomulhaq.v2i2.30.

Fauzi, Ahmad. "Kepemimpinan Kepala Madrasah Dalam Mengembangkan Lembaga Pendidikan Islam." Nidhomul Haq: Jurnal Manajemen Pendidikan Islam 2, no. 2 (6 Desember 2017): 42-53.

Ma`arif, Muhammad Anas. "Analisis Strategi Pendidikan Karakter Melalui Hukuman Preventif." Ta'allum: Jurnal Pendidikan Islam 6, no. 1 (6 Maret 2018): 31-56. https://doi.org/10.21274/taalum.2018.6.1.31-56.

- "Pendidikan Islam Dan Tantangan Modernitas." Nidhomul Haq: Jurnal Manajemen Pendidikan Islam 1, no. 2 (26 Maret 2016): 47-58.

Ma`arif, Muhammad Anas, dan Muhammad Husnur Rofiq. "The Role of Islamic Education Teachers in Improving the Character of Nationalism in Boarding School." EDUKASI: Jurnal Pendidikan Islam 6, no. 1 (21 Juni 2018): 064-078. https://doi.org/10.5281/edukasi.v6i1.323.

Ma’arif, Muhammad Anas. "Analisis Konsep Kompetensi Kepribadian Guru PAI Menurut Az-Zarnuji." ISTAWA 2, no. 2 (2017): 35-60.

Muhaimin, Abdul. "Strategi Pendidikan Karakter Perspektif Kh. Hasyim Asy'ari." Nidhomul Haq: Jurnal Manajemen Pendidikan Islam 2, no. 1 (26 November 2017): 26-37. 